\title{
Influence of Calcium Nitrite on Electrochemical Corrosion Behavior of API X120 Carbon Steel and 316LN Stainless Steel Reinforced Concrete in Marine Environment
}

\author{
Liao Jinsong, Gao Qian*, Li Jing, Fan Lin \\ Department of Construction Management and Real Estate, Chongqing Jianzhu College, Chongqing, \\ 400072, China \\ *E-mail: gao.qian21@protonmail.com; li89561zhang58@ 163.com
}

Received: 20 October 2021 / Accepted: 30 November 2021 / Published: 5 January 2022

\begin{abstract}
This study was carried out to evaluate the corrosion behavior of API X120 carbon steel and 316LN stainless steel reinforced concrete in marine environments with calcium nitrite as an inhibitor. The electrochemical impedance spectroscopy (EIS) technique and SEM were applied to study the concentration effect of calcium nitrite on the corrosion behavior of API X120 carbon steel and 316LN stainless steel reinforced concrete in a $3.5 \% \mathrm{wt} \mathrm{NaCl}$ solution containing calcium nitrite at $\mathrm{pH}$ values of 8,10 and 12. Results showed that double-layer capacitance decreases and charge-transfer resistance increases by increasing the inhibitor concentration which is associated with improvement of the 'blanketing' property of the film. The surface coverage and inhibition efficiency also increase with an increase in inhibitor concentration. A calcium nitrite concentration of $50 \mu \mathrm{M}$ showed $87.7 \%$ and $93 \%$ inhibition efficiency at $\mathrm{pH} 12$ at room temperature for API X120 carbon steel and 316LN stainless steel, respectively. A comparison between the electrochemical corrosion behavior of API X120 carbon steel and 316LN stainless steel reinforced concrete revealed a remarkable decrease in the lifetime of the structure and damage due to reinforcement corrosion of API X120 carbon steel, indicating an increase in the cost associated with monitoring and maintenance. Therefore, replacing the API X120 carbon steel reinforcement with $316 \mathrm{LN}$ stainless steel can decrease the corrosion rate and can also considerably decrease the costs related to expensive equipment for rehabilitation.
\end{abstract}

Keywords: API X120 carbon steel; 316LN stainless steel; Electrochemical impedance spectroscopy; Calcium nitrite; Inhibitor; Corrosion

\section{$\underline{\text { FULL TEXT }}$}

(C) 2022 The Authors. Published by ESG (www.electrochemsci.org). This article is an open access article distributed under the terms and conditions of the Creative Commons Attribution license (http://creativecommons.org/licenses/by/4.0/). 